Agrotrópica 33(1): 17 - 28. 2021.

Centro de Pesquisas do Cacau, Ilhéus, Bahia, Brasil

\title{
Trichoderma spp. REVEALS POTENTIAL AS GROWTH BIO-PROMOTER IN FOREST SEEDLINGS
}

\author{
Andrei Caíque Pires Nunes ${ }^{1 *}$, Aline Pinto dos Santos ${ }^{2}$, Daniel Piotto1, Givaldo Rocha Niella \\ João Carlos Medeiros ${ }^{1}$, Gustavo Laporine Baesso e Silva ${ }^{4}$ \\ ${ }^{1}$ Federal University of Southern Bahia, Training Center in Agroforestry Sciences, 45613-204, Itabuna, BA, Brazil; ${ }^{2}$ State \\ University of Santa Cruz, Pos-graduate Program in Plant Production, 45662-900, Campus Soane Nazaré de Andrade, Rod. \\ Ilhéus/Itabuna, km 16 - Salobrinho, Ilhéus, BA, Brazil; ${ }^{3}$ Executive Commission of the Cacao Agriculture Plan, 45604-811, \\ Rod. Ilhéus/Itabuna, km 26, Ilhéus, BA, Brazil; ${ }^{4}$ Department of Forest Engineering, Federal University of Viçosa, 36570-900, \\ Viçosa, Minas Gerais, Brazil.
}

*Corresponding author address: andrei.nunes@ufsb.edu.br

This work aimed to evaluate the effect of fungus Trichoderma spp. as a growth bio-promoter in seedlings of Eucalyptus grandis $\times$ Eucalyptus urophylla and Cordia trichotoma (Vell.) Arrab. ex Steud. For this purpose, 10 levels of Trichoderma spp. dosages were tested $(0 \mathrm{~g}, 100 \mathrm{~g}, 200 \mathrm{~g}, 300 \mathrm{~g}, 400 \mathrm{~g}, 500 \mathrm{~g}, 600 \mathrm{~g}, 700,800 \mathrm{~g}, 1000 \mathrm{~g})$. Measurements of increment of base diameter (Idbase, $\mathrm{cm}$ ), increment of seedling height (Iheit, $\mathrm{cm}$ ) crown diameter were taken during four months. The experiment was deployed in a randomized complete block design, in a factorial arrangement composed by two species, 10 dosages of Trichoderma spp. and three replications. Differences among Trichoderma spp. dosages were found for Idbase and Iheit, according to F test at $5 \%$ of significance level, verified by analysis of variance. For Idbase, the differences among fungus dosages occurred only in the first month of measurement and for Iheit in the first two months. Trichoderma spp. isolate promoted double base diameter and total height of forest seedlings statically different from control $(0 \mathrm{~g})$. The optimum concentration of Trichoderma spp. was $400 \mathrm{~g}$, which corresponds to $8 \%$ of the total vessel volume. Thus, Trichoderma spp. can be used as a new plant growth bio-promoter, allowing height growth increments during seedlings preparation.

Key words: Forest production, growth increase, nursery, seedlings preparation

Trichoderma spp. revela potencial como bio-promotor de crescimento em mudas florestais. Este trabalho teve como objetivo avaliar o efeito do fungo Trichoderma spp. como biopromotor de crescimento em mudas de Eucalyptus grandis $\times$ Eucalyptus urophylla e Cordia trichotoma (Vell.) Arrab. ex Steud. Para tanto, 10 níveis de dosagens de Trichoderma spp. foram testados $(0 \mathrm{~g}, 100 \mathrm{~g}, 200 \mathrm{~g}, 300 \mathrm{~g}, 400 \mathrm{~g}$, $500 \mathrm{~g}, 600 \mathrm{~g}, 700,800 \mathrm{~g}, 1000 \mathrm{~g}$ ). Medidas de incremento do diâmetro da base (Idbase, $\mathrm{cm}$ ), incremento da altura da muda (Ialt, $\mathrm{cm}$ ) e diâmetro da copa foram realizadas durante quatro meses. $\mathrm{O}$ experimento foi implantado em delineamento de blocos casualizados, em arranjo fatorial composto por duas espécies, 10 dosagens de Trichoderma spp. e três repetições. Diferenças entre as dosagens de Trichoderma spp. foram encontradas para Idbase e Ialt, de acordo com o teste $\mathrm{F}$ ao nível de significância de 5\%, verificado por análise de variância. Para Idbase, as diferenças entre as dosagens dos fungos ocorreram apenas no primeiro mês de medição e para Ialt ocorreram nos primeiros dois meses. A aplicação de Trichoderma spp. promoveu o dobro de crescimento em diâmetro e altura total de mudas florestais estaticamente diferentes do controle $(0 \mathrm{~g})$. A concentração ótima de Trichoderma spp. foi de $400 \mathrm{~g}$, o que corresponde a $8 \%$ do volume total do vaso. Assim, Trichoderma spp. pode ser usado como um novo bio-promotor de crescimento de plantas, permitindo incrementos de crescimento em altura durante a preparação de mudas.

Palavras-chave: Produção florestal, aumento do crescimento, viveiro, preparação de mudas 


\section{Introduction}

Global forest resources have been threatened by indiscriminate exploitation of natural forests, deforestation and the expansion of agricultural crops (Arraes, Mariano e Simonassi, 2012; Laurance, Sayer and Cassman, 2013; Phalan et al., 2013). However, while the global forest area showed a significant decreased in the past 25 years, the total area of planted forests increased from 168 to 278 million hectares (Payn et al., 2015). Planted forests have become important not just as a mean for most of the global wood supply, but also because their contribution to poverty alleviation, conservation of natural forests, and climate-change policies (Buongiorno and Zhu, 2014).

Although there have been a clear shift in the timber supply from natural to planted forests (Payn et al., 2015), this shift requires a continued development of silvicultural techniques aimed at improving current practices and yields. In this regard, it is imperative to look for better practices for seed and seedling production, plantation management and methods to improve plant growth for the sustainable use of forest species. One alternative to boost plant performance is by using bio-promoters, such as Trichoderma spp., which represents a clean technology.

Fungi of the genus Trichoderma spp. occur in tropical regions where it is used in biological control of phytological pathogens in different cultures (Azevedo et al., 2017). The Trichoderma spp. limits the growth of these pathogens on leaves and roots, via antibiosis, competition and parasitism (Medeiros et al., 2010; Asad et al., 2014; Waghunde, Shelake and Sabalpara, 2016). The Trichoderma spp. is an active biological control used in Brazil to inhibit the mycoparasite of the cacao witches 'broom (Bailey et al., 2008; Medeiros et al., 2010; Bastos, 2012).

Species of this genus has been reported in literature as bio-promoters of vegetal growth for many crops, such as rice (Doni et al., 2014; Chagas et al., 2017), beans (Júnior et al., 2014), tomato (Azarmi, Hajieghrari and Giglou, 2011; França et al., 2017), soy (Chagas et al., 2017), Eucalyptus (Azevedo et al., 2017), and rubber trees (Promwee et al., 2014). They are found in soil with a symbiotic relationship with roots of plants, decomposing materials and are rarely related with diseases on plants.
The Trichoderma spp. interacts with the plant, penetrating the root tissue in the first and second layers of cells and only in the intercellular spaces (Brotman et al., 2013). Proteins are involved at the beginning of fixation to root surfaces, acting on the cell wall loosening (Brotman et al., 2013). Trichoderma spp. can establish such interactions and induce changes in plant transcriptome and metabolism (Brotman et al., 2013). These changes lead to the accumulation of antimicrobial compounds that offer plant resistance to a wide range of pathogenic microorganisms (Junior et al., 2014).

There are few papers that evaluate the use of Trichoderma spp. as a promoter of growth on forest timber species. Respectively, "Effect of Trichoderma spp. on Eucalyptus camadulensis clonal seedlings growth" reported by Machado et al. (2015), "Trichoderma spp. in the production of seedling of forest species" by Junges et al. (2016) and "Trichoderma spp. in emergence and growth of cambará seedlings (Gochnatia polymorpha (Less.) Cabrera)" by Azevedo et al. (2017). In spite of these researches, no one reported a practical and consistent result about using Trichoderma spp. as growth biopromoter in forest species. Thus, it is crucial to enlarge studies about the evaluation of Trichoderma spp. effects in the development of natives and exotic trees, aiming an increase of growth and quality of plants.

Considering all these aspects, this work aimed to evaluate the effect of Trichoderma spp. as a growth bio-promoter in seedlings of Cordia trichotoma (Vell.) Arrab. ex Steud. and Eucalyptus grandis $\times$ Eucalyptus urophylla.

\section{Materials and Methods}

\section{Plant material and soil}

Seedlings of $C$. trichotoma and E. grandis $\times E$. urophylla were managed in nurseries until reaching a minimum size of $10 \mathrm{~cm}$ in a $5 \mathrm{~L}$ vessel. Eucalyptus seeds were donated by Universidade Federal de Viçosa (UFV, MG) and seedlings of C. trichotoma were donated by the company Symbiosis Investimentos S. A. These seedlings were watered once a day for 3 months.

The substrate used in each vessel was cocoa planting soil, rich in organic matter and earthworm humus (Table 1). The seedlings were conducted in the laboratory of Heveicultura of "Centro de Pesquisas 
Table 1 - Soil chemical analysis of the cocoa substrate used in the production of seedlings of C. trichotoma and E. grandis $\times E$. urophylla

\begin{tabular}{cccccccc}
\hline \multirow{2}{*}{$\mathrm{pH}^{+}$} & $\mathrm{Al}^{+3}$ & $\mathrm{H}+\mathrm{Al}$ & $\mathrm{Ca}^{+2}$ & $\mathrm{Mg}^{+2}$ & $\mathrm{~K}^{+}$ & $\mathrm{SB}$ & $\mathrm{CEC}$ \\
\cline { 2 - 7 } & \multicolumn{7}{c}{$\mathrm{Cmol}_{\mathrm{c}} \mathrm{dm}^{-3}$} \\
\hline $\mathrm{V}$ & $\mathrm{m}$ & $\mathrm{P}$ & $\mathrm{Fe}^{+3}$ & $\mathrm{Zn}^{+2}$ & $\mathrm{Cu}$ & $\mathrm{Mn}$ & Total clay \\
\hline 93 & 0 & 176 & 361.4 & 9.7 & 3.5 & 78.6 & 74 \\
\hline
\end{tabular}

$\mathrm{Al}+\mathrm{H}$ : potential acidity; SB: sum of bases; CEC: cation exchange capacity; V: percent base saturation; $\mathrm{m}$ : percent aluminum saturation.

do Cacau" from "Comissão Executiva do Plano da Lavoura Cacaueira" (CEPEC/CEPLAC) located in the municipality of Ilhéus-BA, Brazil, at $14^{\circ} 45^{\prime} 28.0^{\prime \prime} \mathrm{S}$ and $39^{\circ} 13^{\prime} 49.5^{\prime \prime} \mathrm{W}$, with an altitude of 58 meters (Af climate according to Köppen classification, Alvares et al., 2013).

\section{Preparation and application of the fungus}

In order to prepare the fungus isolate, it was selected the Trichoderma spp. species with fastest growth at CEPEC/CEPLAC Biocontrol laboratory. This isolate was cultured in rice according to similar protocol used for preparation of Tricovab ${ }^{\circledR}$. After obtaining the isolate of Trichoderma spp., it was inserted into four holes made in each of the four quadrants of the vessel. The isolate was distributed in each of these openings, with 10 levels of dosages $(0 \mathrm{~g}, 100 \mathrm{~g}, 200 \mathrm{~g}, 300 \mathrm{~g}, 400 \mathrm{~g}, 500 \mathrm{~g}$, $600 \mathrm{~g}, 700,800 \mathrm{~g}, 1000 \mathrm{~g})$. The hybrid E. grandis $\times E$. urophylla received all 10 dosages of Trichoderma spp., and C. trichotoma only three dosages $(0,200$ ant $700 \mathrm{~g}$ ), due to the availability of seeds (Table 2).

\section{Experimental design, data collection and statistical analysis}

A randomized complete block design was established in the Heveicultura laboratory, in a factorial arrangement composed by 2 levels of species, 10 levels of Trichoderma spp. isolated for E. grandis $\times E$. urophylla and 3 levels for $C$. trichotoma, totaling 13 treatments and three replicates. Local control was established according to different luminosity strata in this external area.

The growth increment of the seedlings was evaluated monthly for 4 months, after a first measurement done at the beginning of the experiment (calibration of plants).
The traits evaluated in each seedling were: total height $(\mathrm{cm})$, diameter of the base $(\mathrm{cm})$, crown diameter in the north-south direction and crown diameter in the eastwest direction $(\mathrm{cm})$. The height and crown diameter were measured with a measuring tape and the diameter of the base with a caliper.

In the statistical analysis, a Shapiro and Wilk (1965) normality test of the data was made to check the normality at a level of $5 \%$ of probability. The statistical model used to analyze the data of different Trichoderma spp. dosage in different species for each measurement was given by: $\mathrm{Yijk}_{\mathrm{j}}=\mathrm{m}+\mathrm{Bk}+\mathrm{Gi}+\mathrm{Aj}+$ GAij + Eijk, where: Yijk, m, k, i, j, ij, ijk = data vectors, general mean, block effect, species effects, effects of dosages of Trichoderma spp., interaction between Trichoderma spp. dosages $\times$ species and random errors, respectively. B, G, A and GA = incidence matrices for $\mathrm{k}, \mathrm{i}, \mathrm{j}$ and $\mathrm{ij}$, respectively. The Software R was used for this analysis (R Core Team, 2019).

After variance analysis considering the model above, a Scott-Knott test was made in order to group means of Trichoderma spp. dosages. In addition, a quadratic regression model was adjusted to determine the optimal dosage of Trichoderma spp. in the traits and measurements with significant effect of the fungus. For regression analysis, a lack of adjustment analysis was done, since the data was originated from experimental design and three replicates. Moreover, a residual analysis of homoscedasticity and normal distribution verification was set. The $\mathrm{R}$ software ( $\mathrm{R}$ Core Team, 2019) was used for all statistical analysis

Table 2 - Trichoderma spp. dosages for E. grandis $\times$ Eucalyptus urophylla (Eucalyptus) and Cordia trichotoma (C. trichotoma), and relative proportion of Trichoderma spp. isolated in the total amount of substrate $(5 \mathrm{Kg})$

\begin{tabular}{ccc}
\hline $\begin{array}{c}\text { Dosages } \\
(\mathrm{g})\end{array}$ & Species & $\begin{array}{c}\text { Relative } \\
\text { proportion }(\%)\end{array}$ \\
\hline 0 & Eucalyptus and C. trichotoma & 0 \\
100 & Eucalyptus & 2 \\
200 & Eucalyptus and C. trichotoma & 4 \\
300 & Eucalyptus & 6 \\
400 & Eucalyptus & 8 \\
500 & Eucalyptus & 10 \\
600 & Eucalyptus & 12 \\
700 & Eucalyptus and C. trichotoma & 14 \\
800 & Eucalyptus & 16 \\
1000 & Eucalyptus & 20 \\
\hline
\end{tabular}


and to set up graphics. In order to determine the optimal dose of Trichoderma spp., a data series containing different concentrations of the fungus from $0 \mathrm{~g}$ to $1000 \mathrm{~g}$ was simulated.

\section{Results}

\section{Variance analysis}

Data presented normal distribution according to Shapiro and Wilk (1965) normality test at a level of $5 \%$ of probability. Differences among Trichoderma spp. dosages were found for increment of base diameter (Idbase, $\mathrm{cm}$ ) and increment of seedling height (Iheit, $\mathrm{cm}$ ), according to $\mathrm{F}$ test at $5 \%$ of significance level, verified by analysis of variance (Table 3 ). For Idbase, the differences among fungus dosages occurred only in the first month of measurement and for Theit in the first two months. For the traits related to crown diameter, there was no statistical difference among Trichoderma spp. dosages (Table 3).

The statistical differences between species occurred at a 5\% probability level and were more pronounced to Iheit. For Idbase differences between species occurred in the first and second month and for
Iheit those differences were observed for the first, third and fourth months. Considering crown traits, differences between species were found in the first and second months. For species $\times$ fungus interaction there was no statistical significant effect, indicating that Trichoderma spp. effects occurred in the same way for both species (Table 3).

\section{Grouping test of means}

Analyzing traits and measurements in which the effect of Trichoderma spp. was evidenced (base diameter and total seedling height), the Scott-Knott averages group test at a 5\% probability level aided in the detection of the most efficient dosages for seedling growth (Figure 1 and Figure 2). Considering Idbase at the first measurement, the fungus dosages $100 \mathrm{~g}, 300 \mathrm{~g}$, $400 \mathrm{~g}, 500 \mathrm{~g}$ and $600 \mathrm{~g}$ were grouped and are statistically different from $0 \mathrm{~g}$ (control), 1000g, 200g, 700g and 800g (Figure 1). Besides, dosages from $300 \mathrm{~g}$ to $600 \mathrm{~g}$ showed lower variance in plants than other dosages in the first increment (I1). In the others increments (I2, I3 and I4), Scott-Knott test corroborates with variance analysis (Table 3 ) and were found no difference between control $(0 \mathrm{~g})$ and fungus dosages. Thus,

Table 3 - Variance analysis for Trichoderma spp. effects, species and interaction between species $\times$ Trichoderma spp. in each increment measured (Inc.) for the traits increment of base diameter (Idbase), increment of seedling height (Iheit), increase of crown size in the north-south direction (ICNS) and increase of crown size in the east-west direction (ICEW)

\begin{tabular}{|c|c|c|c|c|c|c|c|c|c|}
\hline \multirow{2}{*}{ Inc } & \multirow{2}{*}{ F.V. } & \multicolumn{2}{|c|}{ Idbase $(\mathrm{cm})$} & \multicolumn{2}{|c|}{ Iheit $(\mathrm{cm})$} & \multicolumn{2}{|c|}{ ICNS $(\mathrm{cm})$} & \multicolumn{2}{|c|}{$\mathrm{ICEW}(\mathrm{cm})$} \\
\hline & & p-value & Significant & p-value & Significant & p-value & Significant & p-value & Significant \\
\hline \multirow{4}{*}{1} & Block & 0.378 & n.s & 0.0825 & n.s & 0.1499 & n.s & 0.286 & n.s \\
\hline & Species & $1.90 \mathrm{E}-07$ & $* * *$ & $8.41 \mathrm{E}-06$ & $* * *$ & 0.0137 & $*$ & $1.15 \mathrm{E}-05$ & $* * *$ \\
\hline & Fungus & 0.016 & $*$ & 0.0244 & $*$ & 0.2057 & n.s & 0.366 & n.s \\
\hline & Species $x$ Fungus & 0.941 & $\mathrm{n} . \mathrm{s}$ & 0.7369 & $\mathrm{n} . \mathrm{s}$ & 0.0546 & n.s & 0.834 & $\mathrm{n} . \mathrm{s}$ \\
\hline \multirow{4}{*}{2} & Block & 0.30635 & n.s & 0.5631 & n.s & 0.10926 & n.s & 0.28 & n.s \\
\hline & Species & 0.00314 & $* *$ & 0.1042 & n.s & 0.00461 & $* *$ & 0.0264 & $*$ \\
\hline & Fungus & 0.70734 & n.s & 0.0431 & $*$ & 0.11248 & n.s & 0.8076 & n.s \\
\hline & Species x Fungus & 0.81266 & n.s & 0.3527 & n.s & 0.84388 & n.s & 0.8664 & n.s \\
\hline \multirow{4}{*}{3} & Block & 0.655 & n.s & 0.70101 & n.s & 0.947 & n.s & 0.773 & n.s \\
\hline & Species & 0.652 & n.s & 0.00339 & $* *$ & 0.369 & n.s & 0.132 & n.s \\
\hline & Fungus & 0.571 & n.s & 0.40691 & $\mathrm{n} . \mathrm{s}$ & 0.121 & n.s & 0.327 & n.s \\
\hline & Species x Fungus & 0.246 & n.s & 0.08567 & $\mathrm{n} . \mathrm{s}$ & 0.327 & n.s & 0.14 & n.s \\
\hline \multirow{4}{*}{4} & Block & 0.0942 & n.s & 0.8025 & n.s & 0.941 & n.s & 0.4153 & n.s \\
\hline & Species & 0.0591 & n.s & 0.0219 & $*$ & 0.81 & n.s & 0.5713 & n.s \\
\hline & Fungus & 0.4294 & n.s & 0.9831 & n.s & 0.895 & n.s & 0.5099 & n.s \\
\hline & Species $x$ Fungus & 0.8853 & n.s & 0.9022 & n.s & 0.687 & n.s & 0.0849 & n.s \\
\hline
\end{tabular}

Inc: increment measured; *: significant at $10 \%$ of probability; ** significant at $5 \%$ of probability; ***: significant at $1 \%$ of probability; n.s: not significant F.V.: factor of variation. 

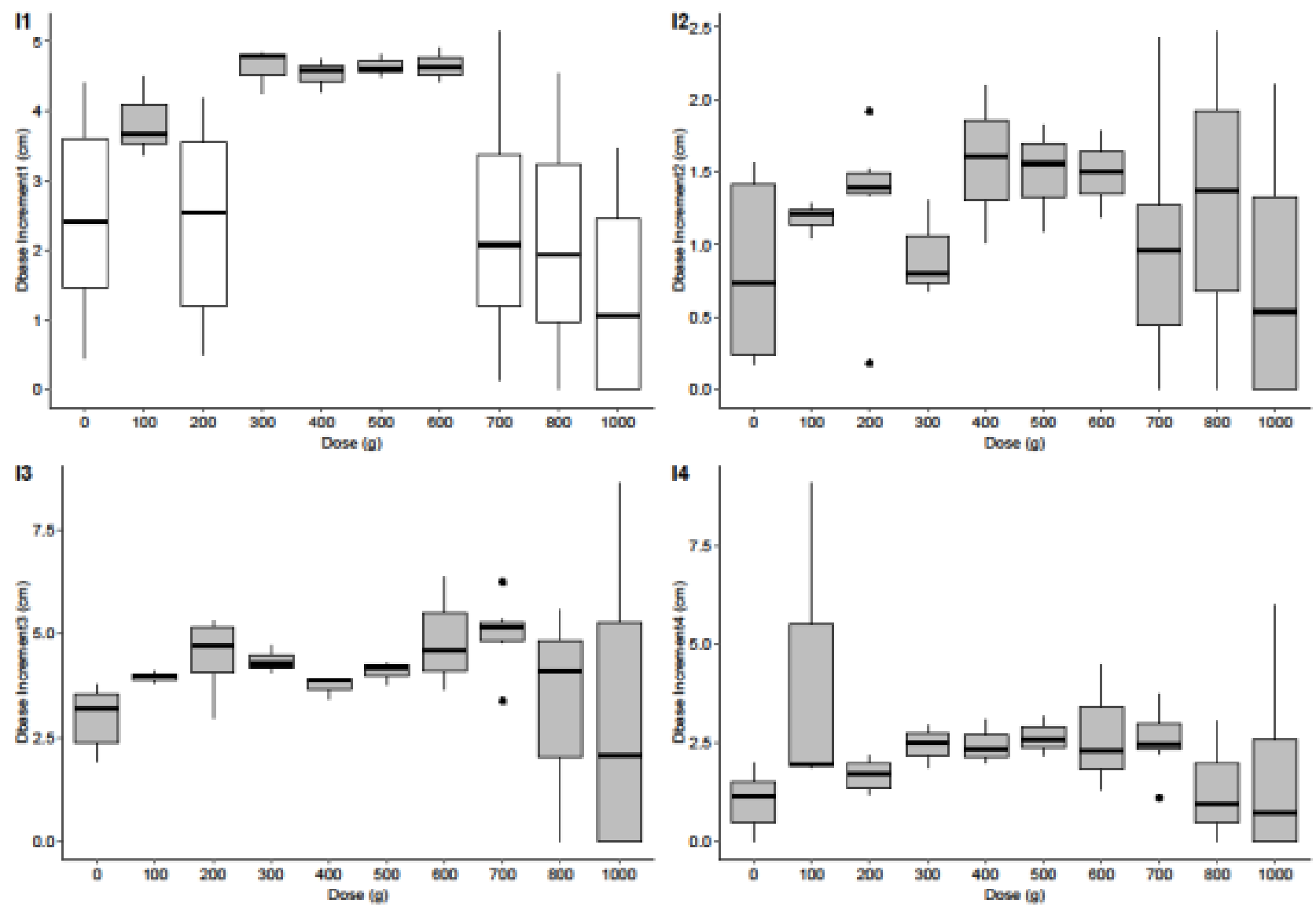

Figure 1. Representative graphic of Scott-Knott test at 5\% probability level, considering increment of base diameter means (cm) for Trichoderma spp. dosages in each increment (I1, I2, I3 and I4). In the boxplot, each color indicates group of means for fungus dosage, which are statistically different one another according to Scott-Knott test at $5 \%$ of probability.

Trichoderma spp. dosages of 100g, 300g, 400g, 500g and $600 \mathrm{~g}$ provided increase of base diameter in forest seedlings in relation to no application of the fungus for one month. Moreover, some dosages as $700 \mathrm{~g}, 800 \mathrm{~g}$ and $1000 \mathrm{~g}$ caused no effect on Idbase in the first month (Figure 1).

The increase of total height caused by Trichoderma spp. isolate was verified in the first and second month, according to Scott-Knott test (Figure 2). In the first measurement, the dosages $100 \mathrm{~g}, 300 \mathrm{~g}, 400 \mathrm{~g}, 500$ and $600 \mathrm{~g}$ provided better indices of Iheit then control $(0 \mathrm{~g})$, which was statically different to $200 \mathrm{~g}, 700 \mathrm{~g}, 800 \mathrm{~g}$ and $1000 \mathrm{~g}$ (Figure 2). Besides, dosages from $300 \mathrm{~g}$ to 500 showed lower variance in plants than other dosages in the first increment (I1). Similar to the first increment measured, in the second month the dosages $100 \mathrm{~g}, 200 \mathrm{~g}$, $300 \mathrm{~g}, 400 \mathrm{~g}, 500 \mathrm{~g}$ and $700 \mathrm{~g}$ were statically different and provided higher Iheit than $0 \mathrm{~g}, 600 \mathrm{~g}, 800 \mathrm{~g}$ and $1000 \mathrm{~g}$ (Figure 2). As verified to Idbase, Trichoderma spp. was capable of providing increase of total height in forest seedlings in relation to no application of the fungus. For a visual certification of the effect of Trichoderma spp. the supplementary material can be accessed (Figure S1).

\section{Regression analysis}

The quadratic regression model was adjusted for Idbase and Iheit at the first increment measured. Regression model was statistically significant for both traits at $1 \%$ and $5 \%$ levels of probability (Idbase pvalue: 0.004216 ; Iheit $p$-value: 0.007368 ). The lack of adjustment analysis proved the suitability of the models at $1 \%$ and $5 \%$ levels of probability (Idbase p-value: 0.1322; Iheit p-value: 0.2974). Thus, the models 

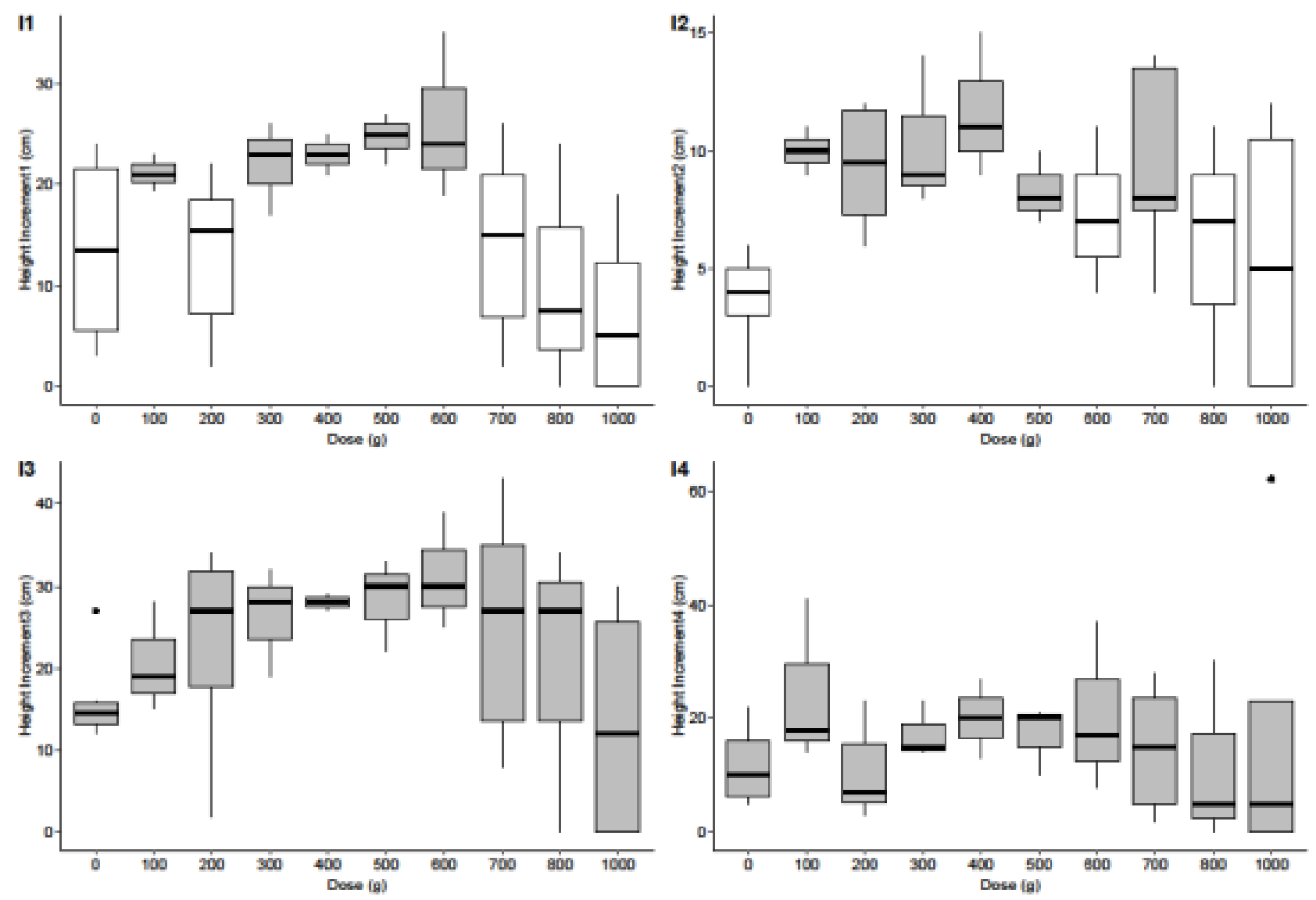

Figure 2. Representative graphic of Scott-Knott test at 5\% probability level, considering increment of height of the seedling means $(\mathrm{cm})$ for Trichoderma spp. dosages in each increment (I1, I2, I3 and I4). In the boxplot, each color indicates group of means for fungus dosages, which are statistically different one another according to Scott-Knott test at $5 \%$ of probability.

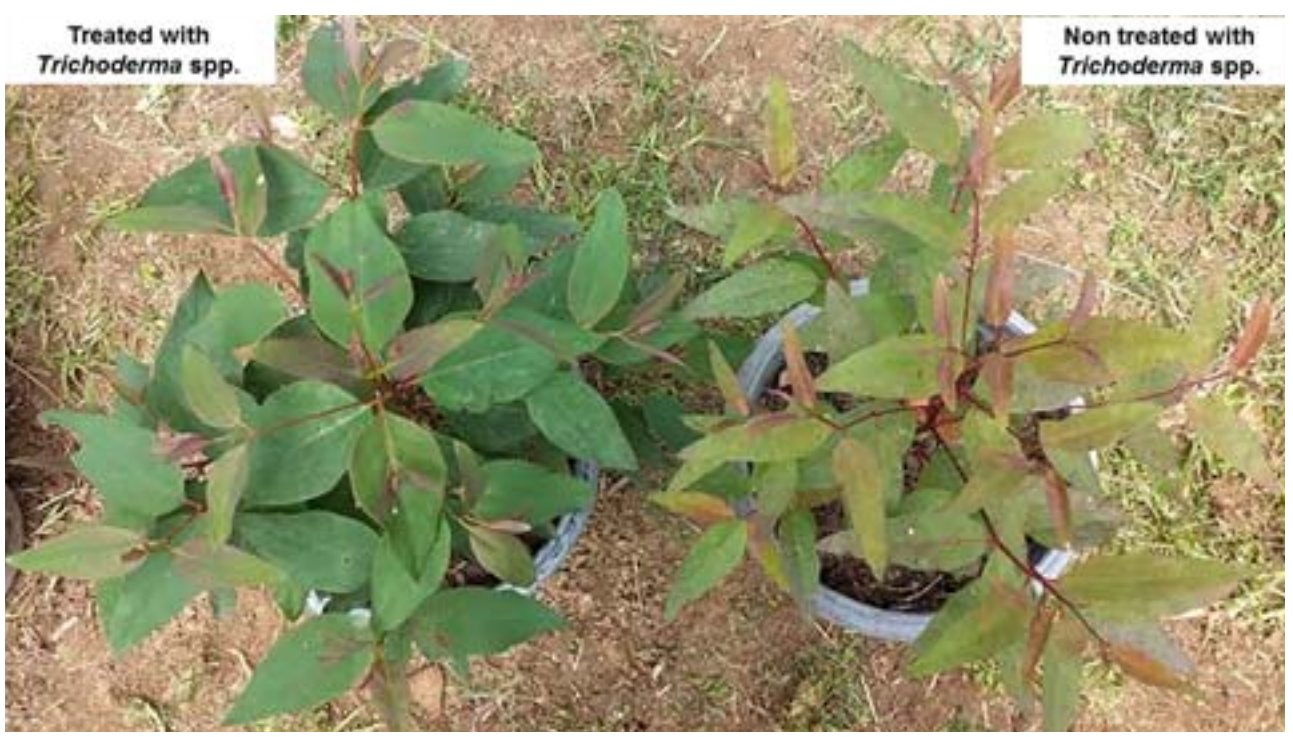

Figure S1. Supplementary material representative of the Trichoderma spp. effect on the Eucalyptus seedling. On the left the material treated with the fungus and on the right the untreated material. The difference in greenish color is clear and occurred in the same way for all repetitions. 
generated can be used for predicting Idbase and Iheit for E. grandis $\times E$. urophylla and C. trichotoma seedlings.

The simulated data series was used as input in the models adjusted and fitted values of Idbase and Iheit were generated and plotted for the first increment (Figure 3 and Figure 4). Considering Idbase, the model adjusted presented an adjusted $\mathrm{r}^{2}$ of 0.54 (corrected for the lack of adjustment and the optimum concentration of Trichoderma spp. was $400 \mathrm{~g}$, which corresponds to $8 \%$ (Table 2) of the total vessel capacity (Figure 3). This optimum concentration provided twice as much Idbase for treated plants in relation to control $(0 \mathrm{~g})$.

The model adjustment for Iheit provided an adjusted $\mathrm{r}^{2}$ of 0.57 (corrected for the lack of adjustment) and the optimum dose of Trichoderma spp. was $400 \mathrm{~g}$ as presented for Idbase and corresponds to $8 \%$ (Table 2) of the total capacity of the vessel used for seedlings cultivation (Figure 4). This optimum concentration provided twice as much Iheit for treated plants in relation to control $(0 \mathrm{~g})$.

\section{Discussion}

The different responses of Trichoderma spp. isolate on the base diameter and height of seedlings, contrasted with crown traits corroborates with the action of the fungus on roots, which promotes better absorption of nutrients of the soil, empowering internal seedlings processes and nutrient translocations (Brotman et al., 2013). So, with the same crown diameter, plants are

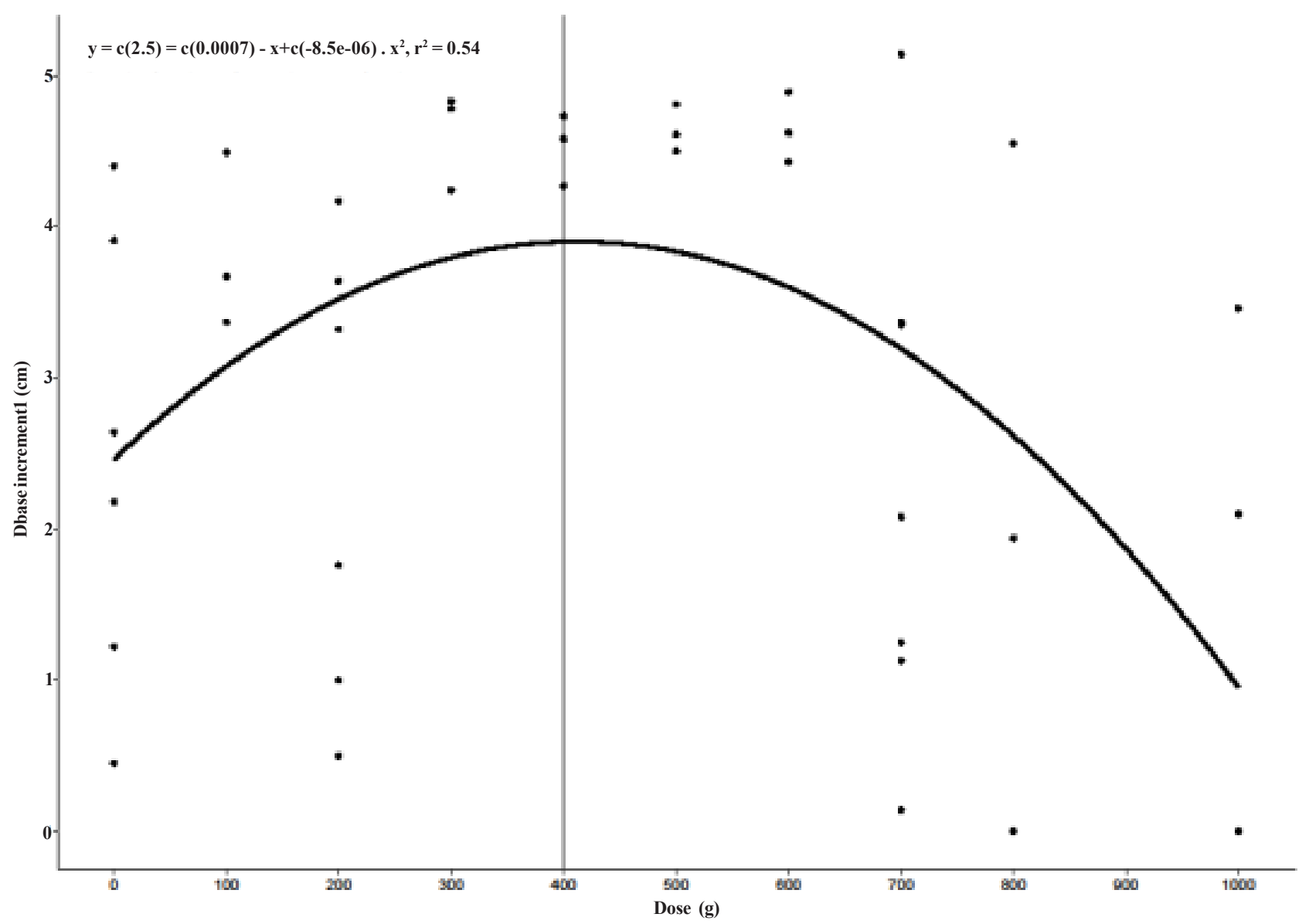

Figure 3. Representative graphic of quadratic regression model fitted values adjusted for Idbase ( $\mathrm{cm}$ ) in the first increment measured. Predictions were made considering inputs of a data series of Trichoderma spp. dosages varying from $0 \mathrm{~g}$ to $1000 \mathrm{~g}$, by ten units. The vertical line indicates the Trichoderma spp. dose, which provides the maximum Idbase value predicted by the model. Points indicates data collected in the experiment for E. grandis $\times$ E. urophylla and C. trichotoma seedlings and used to adjust the model. 


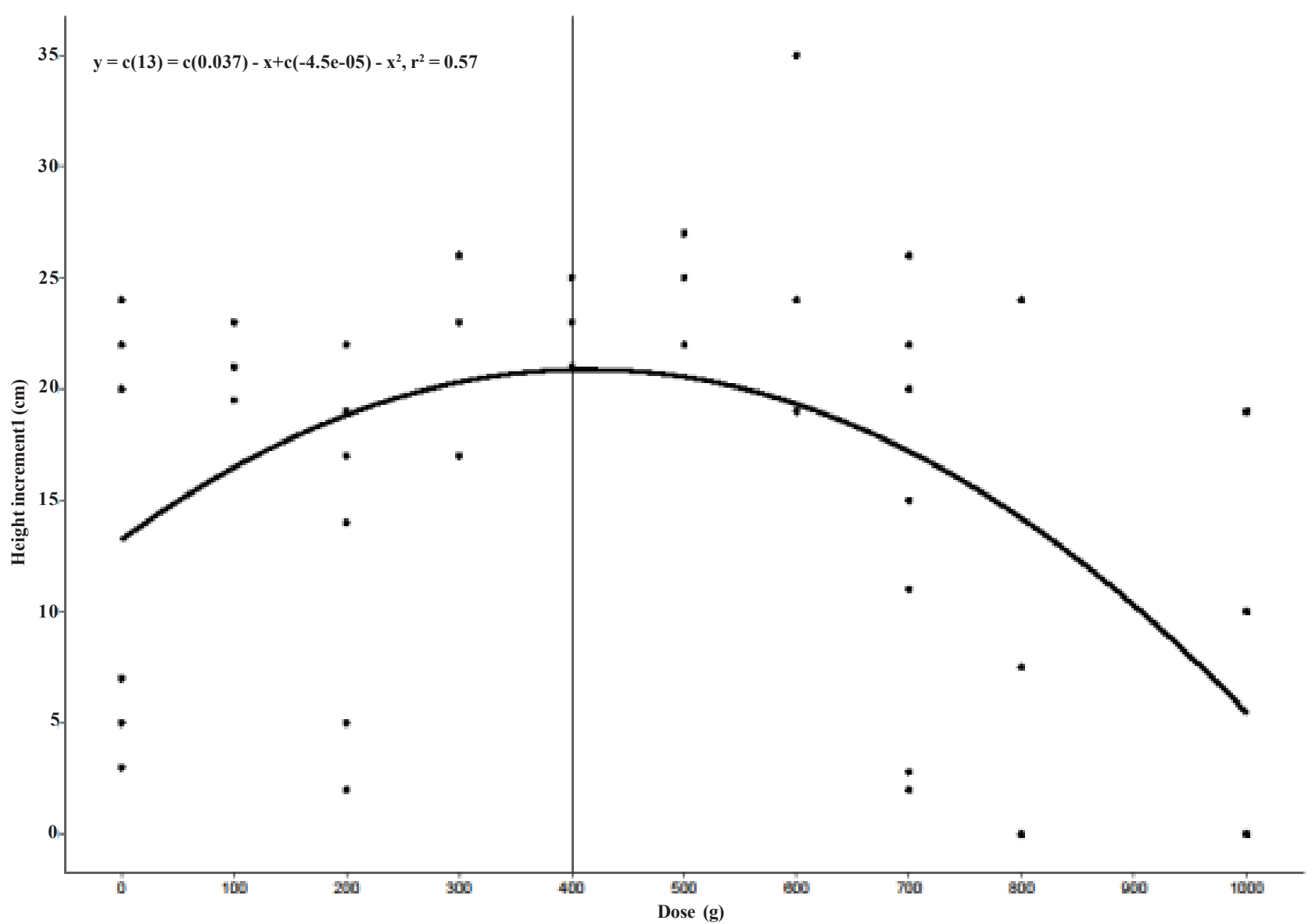

Figure 4. Representative graphic of quadratic regression and fitted values for Iheit $(\mathrm{cm})$ in the first increment measured. Predictions were made considering inputs of a data series of Trichoderma spp. dosages varying from $0 \mathrm{~g}$ to $1000 \mathrm{~g}$, by ten units. The vertical line indicates the Trichoderma spp. dose, which provides the maximum Iheit value predicted by the model. Points indicates data collected in the experiment for E. grandis $\times$ E. urophylla and C. trichotoma seedlings and used to adjust the model.

capable of take more nitrogen and water from the substrate and improve photosynthetic ability, leading to high chlorophyll rates and better radiation absorption. It was clearly visually verified, once seedlings treated with Trichoderma spp. presented higher green leaves intensity than no treated ones (Figure S1).

The double growth for both traits Idbase and Iheit caused by Trichoderma spp. is important for silvicultural sector, which aims improving seedlings production and better yields along the years. Producing large quantities of seedlings represents a crucial step for the good development of forest stands. The use of high quality seedlings increases their survival in the stands, as well as can decrease the need for constant cultural treatments (Azevedo et al., 2017). Thus, Trichoderma spp. isolate has potential to ensure high quality in the production of forest propagules and to represent technological advances in the production of seedlings with good adaptation and growth. Another advantage relates to lower variability of seedling size for the effective dosages ( $300 \mathrm{~g}$ to $500 \mathrm{~g}$ ) which is desired for industrial nurseries.

Few studies have applied isolates of Trichoderma spp. in the production of forest seedlings. According to Azevedo et al. (2017) this fungus promoted rooting of mini cuttings, once as it releases substances that are assimilated by plant roots. These authors observed that Eucalyptus camaldulensis mini cuttings treated with Trichoderma virens and Trichoderma harzianum achieved higher rates of seedling development and quality than no treated ones. Promwee et al. (2014) found Trichoderma species could solubilize insoluble phosphate into available phosphate through organic acid production and they 
could promote growth of rubber tree under greenhouse conditions. Machado et al. (2015) evaluated seedling emergence and growth of cambará (Gochnatia polymorpha) and found potential use of Trichoderma spp. as seedling growth promoters for this species. Azevedo et al. (2017) studied the development and quality of Eucalyptus camaldulensis clonal seedlings under the effect of Trichoderma spp. These authors found that the use of this fungus promoted higher development of seedlings in relation to control (not treated seedlings). In all those studies Trichoderma spp. presented potential as a bio-stimulant of plant growth as in our study.

Regarding agronomic species, there are some papers that reported fungus effect on plant growth. Gravel, Antoun and Tweddell (2007) used Trichoderma spp. and observed the increase of fresh weight of both shoot and roots of tomato plants. Carvalho et al. (2011) found significant effect caused by an isolated from Trichoderma harzianum on seed beans for shoot length. Santos, Mello e Peixoto (2010) reported significant effect of Trichoderma spp. on passion fruit mini cuttings fresh and drought matter increment. Azarmi, Hajieghrari and Giglou (2011) reported Trichoderma spp. significant effects on tomato shoot height, shoot diameter, shoot fresh, dry weight, root fresh and dry weight. Junior et al. (2014) found significant effect of Trichoderma spp. in beans, improving biomass production, nodulation and productivity. All authors reported the fungus action may be related to improving on nutrients supplying and pathogen protection.

The promotion of plant growth by fungi is related to the production of plant hormones, vitamins or conversion of materials to a useful plant form, mineral absorption, translocation and pathogen control (Chávez, Pereira and Machuca, 2014; Larriba et al., 2015). Moreover, Trichoderma spp. can colonize whole root surfaces and can be defined as opportunistic plant symbionts. Root tissue penetration is generally limited to first or second cell layers and only to intercellular spaces. Proteins are involved in early attachment to root surfaces, acting on plant cell wall loosening, cellulose fiber expansion, thus facilitating the action of a vast arsenal of cell wall degrading cellulases
(Brotman et al., 2013). Trichoderma spp. is able to establish such interactions and induce changes in plant transcriptome and metabolism (Brotman et al., 2013). Such changes lead to accumulation of antimicrobial compounds that offer plant resistance to a wide range of pathogenic microorganisms (Junior et al., 2014). Thus, the improved growth enhanced plant promoted by Trichoderma spp. application is due to in its ability to solubilize many important nutrients to the plant and stimulates production of growth hormones.

Regarding time action of Trichoderma spp. it was verified pronounced effect of the fungi only in the beginning of the measurements (Figure 1 and Figure 2 ). Reports in the literature regarding time action of Trichoderma spp. are scarce. The majority of papers published results only in the period of success of the fungus. Despite this fact, Ouahmane et al. (2006) found effect arbuscular mycorrhizal on height growth of Cupressus atlantica for one year in the field. Horton, Cázares and Bruns (1998) also reported long term fungus effect on tree individuals. These authors verified the effect of ectomycorrhizal, vesiculararbuscular and dark septate fungal on Pinus muricata for five months in the field. ContrerasCornejo (2009) found early Trichoderma spp. action on Arabidopsis in culture medium. In spite of field experiments, limited environments seem to limit fungus action.

In our work, the limited rate of nutrients (Table 1) and substrate displayed in the vessel could limit the Trichoderma spp. action through time. Thus, additional applications of fertilizers and Trichoderma spp. should be done to maintain relevant growth rates if long term increments are desired. Regarding rustification in the final stages of seedlings production, application of Trichoderma spp. seems to be ideal, since it can promotes twice much base diameter and high of the seedlings one month before forest commercial implantation.

The optimum concentration of Trichoderma spp. that promoted maximum base diameter and total height (Figure 1 and Figure 2) of the plants was $400 \mathrm{~g}$, which corresponds to $8 \%$ of the total vessel volume (Table 2). This result plays an important practical role in the forest sector, since this proportion of $8 \%$ can be tested in any kind of seedlings 
establishment scheme. Tested as a plant growth biopromoter, Trichoderma spp. can be applied in any crop in the proportion of $8 \%$ in relation to all volume occupied by roots. So, if soil fertilization is guaranteed by soil management and $8 \%$ of total plant root volume in the vessels or in the field is correspondent to Trichoderma spp. high levels of yield can be potentially achieved in the crop tested. Moreover, considering Trichoderma spp. preparation used in our work is very cheap, this technology has great potential to be applied by small farmers and large farmers. Thus, the use of Trichoderma spp. preparation on seedlings growth can represent a breakthrough on the way of seedlings of forest species are produced.

Larger dosages of Trichoderma spp. caused toxic effect on plants, reducing diameter and height increments (Figure 1 and Figure 2). In the vessels containing those dosages, it was observed excess humidity in the roots. Considering the dosages of 700 to $1000 \mathrm{~g}$ the appearance of fly larvae was verified due to the rice used in the preparation of Trichoderma spp., which led to high humidity levels. So, for general application of this plant growth bio-promoter discovered in this work, the soil humidity and drainage should be considered.

\section{Conclusion}

Trichoderma spp. isolate promotes significant increment in base diameter and total high of forest seedlings at the first and second months of application. The optimum concentration of Trichoderma spp. is $400 \mathrm{~g}$, which corresponds to $8 \%$ of the total vessel volume. This concentration provides twice much base diameter and total height of seedlings in relation to control. Thus, Trichoderma spp. can be used as a new plant growth bio-promoter, allowing high growth increments during seedlings preparation.

\section{Acknowledgments}

The authors thank the Federal University of Southern Bahia (UFSB), Symbiosis Investments S. A. and the Executive Committee of the Cacao Plantation Plan (CEPLAC) for their support.

\section{Literature Cited}

ALVARES, C. A. et al. 2013. Köppen's climate classification map for Brazil. Meteorologische Zeitschrift, 22(6):711-728.

ARRAES, R. A.; MARIANO, F. Z.; SIMONASSI, A. G. 2012. Causas do desmatamento no Brasil e seu ordenamento no contexto mundial. Revista Econnomia e Sociologia Rural 50(1):119-140.

ASAD, S. A. et al. 2014. Biocontrol efficacy of different isolates of Trichoderma against soil borne pathogen Rhizoctonia solani. Polish Journal of Microbiology 63(1):95-103.

AZARMI, R.; HAJIEGHRARI, B.; GIGLOU, A. 2011. Effect of Trichoderma isolates on tomato seedling growth response and nutrient uptake. African Journal of Biotechnology 10(32):5850-5855.

AZEVEDO, G. B. et al. 2017. Efeito de Trichoderma spp. no crescimento de mudas clonais de Eucalyptus camaldulensis. Science For. 45(114):343-352.

BAILEY, B. A. et al. 2008. Antibiosis, mycoparasitism, and colonization success for endophytic Trichoderma isolates with biological control potential in Theobroma cacao. Biological Control 46(1):24-35.

BASTOS, C. N. 2012. Isolate of Trichoderma brevicompactum for the control of cocoa witches' broom disease: preliminary results. Agrotrópica (Brasil) 24(1):5-10.

BROTMAN, Y. et al. 2013. Trichoderma-plant root colonization: escaping early plant defense responses and activation of the antioxidant machinery for saline stress tolerance. Plos Pathogens 9(4)1-15.

BUONGIORNO, J.; ZHU, S. 2014. Assessing the impact of planted forests on the global forest economy. New Zealand Journal of Forestry Science 44(Suppl 1):S2.

CARVAlHO, D. D. C. et al. 2011. Controle de Fusarium oxysporum f. sp. phaseoli in vitro e em sementes, e promoção do crescimento inicial do feijoeiro comum por Trichoderma harzianum. Tropical Plant Pathology 36(1):28-34. 
CHAGAS, L. F. B. et al. 2017. Trichoderma na promoção do crescimento vegetal. Journal of Neotropical Agriculture 4(3):97-102.

CHÁVEZ, D.; PEREIRA, G.; MACHUCA, A. 2014. Estimulación del crecimiento en plántulas de Pinus radiata utilizando hongos ectomicorrícicos y saprobios como biofertilizantes. Bosque (Brasil) 35(1):57-63.

CONTRERAS-CORNEJO, H. A. et al. 2009. Trichoderma virens, a Plant Beneficial Fungus, Enhances Biomass Production and Promotes Lateral Root Growth through an AuxinDependent Mechanism in Arabidopsis. Plant Physiology 149:1579-1592.

DONI, F. et al. 2014. Physiological and growth response of rice plants (Oryza sativa L.) to Trichoderma spp. inoculants. Amb Express 4(1):45.

FRANÇA, D. V. C. et al. 2017. Trichoderma spp. isolates with potential of phosphate solubilization and growth promotion in cherry tomato. Pesquisa Agropecuária Tropical (Brasil) 47(4):360-368.

GRAVEL, V.; ANTOUN, H.; TWEDDELL, R. J. 2007. Growth stimulation and fruit yield improvement of greenhouse tomato plants by inoculation with Pseudomonas putida or Trichoderma atroviride: Possible role of indole acetic acid (IAA). Soil Biology and Biochemistry 39(8):1968-1977.

HORTON, T. R.; CÁZARES, E.; BRUNS, T. D. 1998. Ectomycorrhizal, vesicular-arbuscular and dark septate fungal colonization of bishop pine (Pinus muricata) seedlings in the first 5 months of growth after wildfire. Mycorrhiza 8:11-18.

JUNGES, E. et al. 2016. Trichoderma spp. na Produção de Mudas de Espécies Florestais. Floresta e Ambiente 23(2):237-244.

JÚNIOR, A. F. C. et al. 2014. Promoção de crescimento em feijão-caupi inoculado com rizóbio e Tricoderma spp. no cerrado. Revista Caatinga 27(3):190-199.

LARRIBA, E. et al. 2015. Endophytic colonization of barley (Hordeum vulgare) roots by the nematophagous fungus Pochonia chlamydosporia reveals plant growth promotion and a general defense and stress transcriptomic response. Journal of Plant Research 128(4):665678.

LAURANCE, W. F.; SAYER, J.; CASSMAN, K. G. 2014. Agricultural expansion and its impacts on tropical nature. Trends in ecology \& evolution 29(2):107-116.

MACHADO, D. F. M. et al. 2015. Trichoderma spp. na emergência e crescimento de mudas de Cambará (Gochnatia polymorpha (Less.) Cabrera). Revista Árvore (Brasil) 39(1):167-176.

MEDEIROS, F. H. V. et al. 2010. A novel, integrated method for management of witches' broom disease in Cacao in Bahia, Brazil. Crop Protection 29(7):704-711.

OUAHMANE, L. et al. 2006. Improvement of Cupressus atlantica Gaussen growth by inoculation with native arbuscular mycorrhizal fungi. Journal of Applied Microbiology 103(3):683-690.

PAYN, T. et al. 2015. Changes in planted forests and future global implications. Forest Ecology Management 352:57-67.

PHALAN, B. et al. 2013. Crop expansion and conservation priorities in tropical countries. PloS one 8(1): e51759.

PROMWEE, A. et al. 2014. Phosphate Solubilization and Growth Promotion of Rubber Tree (Hevea brasiliensis Muell. Arg.) by Trichoderma Strains. Journal of Agricultural Science 6(9):1-13.

R Core Team, 2019. R: A language and environment for statistical computing. R Foundation for Statistical Computing, Vienna, Austria. Available at: URL https://www.R-project.org/.

SANTOS, H. A.; MELlO, S. C. M.; PEIXOTO, J. R. 2010. Associação de isolados de Trichoderma spp. e ácido indol-3- butírico (AIB) na promoção de enraizamento de estacas e crescimento de maracujazeiro. Bioscience Journal 26(6):966-972.

SHAPIRO, S.; WILK, M. 1965. An Analysis of Variance Test for Normality (Complete Samples). Biometrika 52(3/4):591-611. 
WAGHUNDE, R. R.; SHELAKE, R. M.; environment. African Journal Agricultural SABALPARA, A. N. 2016. Trichoderma: A Research 11(22):1952-1965.

significant fungus for agriculture and 